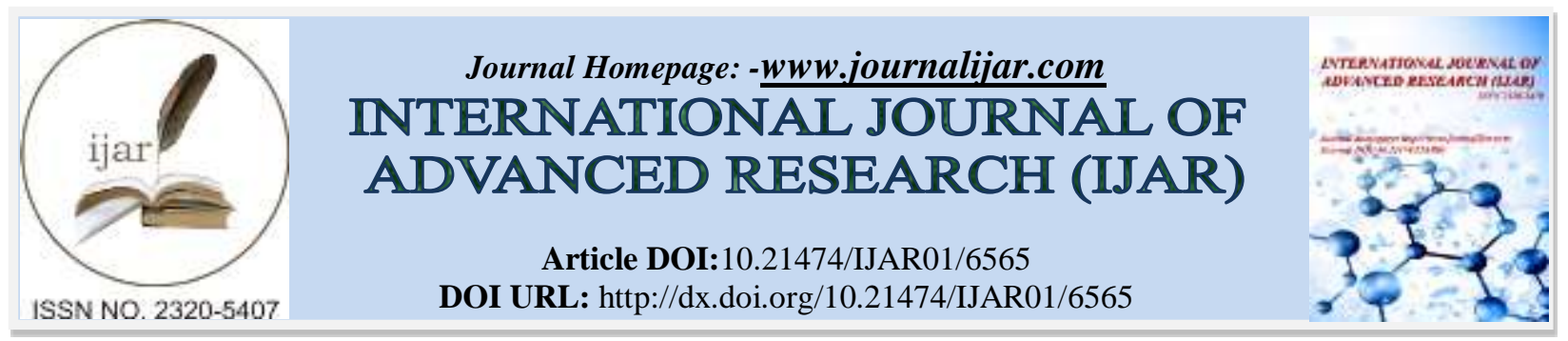

RESEARCH ARTICLE

\title{
ANALYSIS OF GREEN FREIGHT TRANSPORTATION PRACTICES AS A DIFFERENTIATION STRATEGY IN THE FREIGHT TRANSPORT INDUSTRY.
}

T. N. S Desilva and D. R. Ratnajeewa.

Department of Management and Finance, General Sir John Kotelawala Defence University, Sri Lanka.

\section{Manuscript Info}

Manuscript History

Received: 17 December 2017

Final Accepted: 19 January 2018

Published: February 2018

Keywords:-

Green Practices, Competitive

Advantage, Freight Transportation,

Differentiation.

\section{Abstract}

The environmental destruction due to human activities in the current era has become the focus of society, governments and manufactures. Since transport has a negative impact on the environment it has become one of the areas with considerable potential within this scope. The proactive approach to address these negative environmental impacts from transport is named as Green Freight practices. The motivation to adopt green practices is the ability to use it as a differentiation strategy. This research was conducted to identify the relationship between Green freight transport practices and differentiation strategy. The primary objective of this study was to analyse the relationship between green freight transportation practices and differentiation strategies of an organization in order to gain competitive advantage. As the sample of the study initially seventy five companies were selected in Colombo district. The sample was selected based on the convenience sampling method as it was difficult to obtain data from certain organizations. This study focused on freight transport organizations where green activities already exist. Primary data was obtained through a questionnaire survey and interviews with the executives and the management staff of organizations. Twelve green freight transport practices were considered. SPSS was used for data analysis. The correlation matrix was derived during the analysis. The findings state that there is a positive relationship between six of the green practices out of the twelve with differentiation strategy. The six practices are transporting in bulk packages, direct transportation, using of trained drivers, avoiding congestion hours, using a transport time table and using multiple modes to transport freight. Transporting goods in bulk packages, direct transportation, use of trained drivers and using a transport time table have significantly strong positive correlations with differentiation (at the significance level of 90 percent).Therefore it can be concluded that the implementation of practices such as transporting in bulk packages, direct transportation, using of trained drivers and using a transport time table contributes to enhance the differentiation of freight transporters.

Copy Right, IJAR, 2018,. All rights reserved.

Corresponding Author:- T.N.S Desilva.

Address:- Department of Management and Finance, General Sir John Kotelawala Defence

University, Sri Lanka. 


\section{Introduction:-}

This section discusses about the problem addressed by this study and the background of the study. Further it discusses the main objective of the study and its significance.

In the past few decades the performance of economic and non-economic activities has thoroughly required them to be friendly to the environment. The environmental destruction due to human activities in the current era has become the focus of society, governments and manufactures (Lo, 2013). Since transport has a negative impact on the environment it has become one of the areas with considerable potential within this scope of reducing the negative environmental impact of human activities. The proactive approach to addressing and eliminating the negative environmental impacts from the transport process is named as 'green freight transport' (Staš et al., 2015). Going green is also defined as taking steps to conserve energy, reduce pollution and save money. Further it means contributing towards maintaining the natural ecological balance in the environment and preserving the planet and its natural systems and resources and it is about taking steps whether big or small to minimize the harm done by a particular person's or organization's activities to the environment. In practice 'going green' means adopting five basic principles namely reduce pollution, conserve resources, conserve energy, reduce consumption and waste to protect the earth's ecological balance. The concept of green practices has gone through a remarkable transformation as a business strategy since its first appearance in the 1970's. Business organizations have gradually realized the importance of green practices as means of achieving competitive advantage over rivals in the industry.

Greenhouse gas emission in policy and practice has caught the attention of companies across many industries. In transportation emissions are a prominent topic. Regarding transportation three areas with high environmental impacts can be highlighted. They are the operation of vehicles including the fuel choice, the disposal of the vehicles and the constructions of transport networks related to infrastructure and inventory locations (Pålsson and Kovács, 2014). Road freight transport is the dominant mode of movement of goods across the countries. On the other hand road transport has revealed significant weaknesses contributing to considerable $\mathrm{CO}_{2}$ emissions, accidents, increased noise level, road congestion and wear and tear of infrastructure (Marchet, et al., 2014).

A strong increase is forecasted especially in road freight. Freight transport in Europe rose by 90 percent between 1990 and 2005. In the same period the demand for road freight transport as the major polluter of all land based transport modes increased even more (by 138 percent). Subsequently, the involvement of road freight transport to the direct CO2 emissions is 20 percent. (Buhler and Jochem, n.d.)

Over the past decade while many new management approaches and principles have been introduced to address the social, economic and environmental issues associated with the manufacturing and transportation of products and services, new and critical challenges have emerged. On the other hand, consumers show an increasing concern for the environment and are willing to pay premium prices for eco-products. This trend has important implications for the manufacturing and transportation. It is likely to cause changes in business mindsets and objectives.

Under the scope of this research, the study discusses about how green freight practices in the freight transportation process would involve in changing the face of differentiation strategies of the freight transport industry.

Competitive advantage is a set of unique features of an organization and its products that is perceived by the target market as significant and superior to the competitors. It is the reason behind brand loyalty and why a person may prefer one product or service over another. There are three different types of competitive advantages. They are cost, product or service differentiation and niche strategies. When talking about differentiation strategies it calls for the development of a product or service that offers unique characteristics that are valued by customers and that customers perceive to be better than or different from the products of the competitors.

With the contemporary situation in the present business environment in Sri Lanka, sustainability and green practices have been controversial because of the question whether it supports as a differentiation strategy for the particular organization or not. There are three specific environmental issues that a freight transportation policy could address which are reduction of $\mathrm{CO}_{2}$ emission, reduction of $\mathrm{NO}_{\mathrm{x}}$ (Nitric Oxides) and particulate matters' emission and reduction of noise.

This research tries to determine the relationship between green practices in freight transportation and differentiation of an organization to gain competitive advantage. The main objective of the research is to determine the relationship 
between green freight transport practices and differentiation strategies of an organization to gain competitive advantage. Most of the previous studies have not looked upon these 'go green' activities as contributing towards differentiation of an organization from its competitors. Therefore this study fills this research gap that was existing.

\section{Methodology:-}

This section presents in depth about the methodology that was adopted in conducting this research and includes sampling, data collection and analysis methods.

In this study the research problem was to find out whether green practices in freight transportation has an impact on differentiation strategies of the organization. Hence the conceptual framework was prepared by using differentiation strategy as the dependent variable and twelve green freight practices were selected as independent variables. Figure 1 depicts the conceptual frame work and Figure 2 indicates the twelve practices reflected upon. A questionnaire was then constructed based on the conceptual framework derived from the literature review.

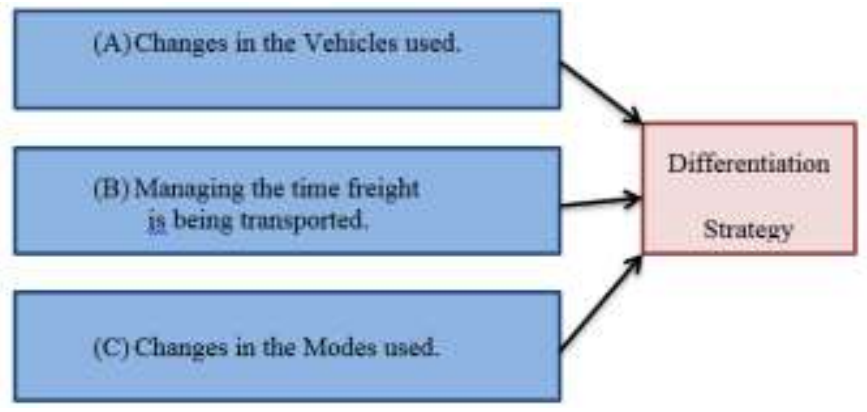

Figure 1:- Conceptual framework

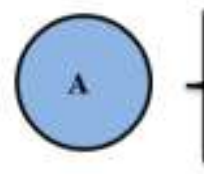

01) The use of alternative fuel vehicle:

02) Changing the vehicles in the same mode of transport

03) Using better shape designed vehicles

04) Using trained drivers

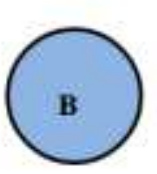

05) Direct transportation

06) Using a route plan

07) Reducing the travelling of empty vehicles

08) Using a transport time table

09) Transporting freight avoiding the congestion hours

10) Transporting in bulk packages

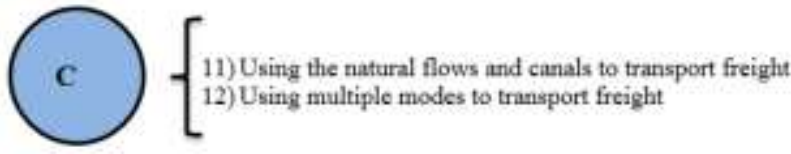

Figure 2:- Practices considered in the study

The primary objective of this study was to analyse the relationship between green freight transportation practices and differentiation of an organization in order to gain competitive advantage. Therefore this study had to consider freight transport organizations where green freight activities already exist. As the initial sample of the study seventy five companies were selected in the Colombo district. The sample was selected based on the non-probability method of convenience sampling method as it was difficult to obtain data from certain organizations. Primary data was obtained through a questionnaire survey and interviews with the executives and the management staff of organizations. Out of the seventy five questionnaires which were distributed, only sixty two organizations responded with a response rate of 82.6 percent. Out of those also, since the research was carried out to identify the relationship between green practices in freight transportation and differentiation, finally a sample of fifty companies which practice green freight activities were selected. 
Twelve green freight transport practices were considered in the questionnaire as mentioned above. Data was collected from the employees who are involved in the transport process of the organizations and belong to the executive level and management level of the companies. The software 'SPSS' was used for data analysis. The main analysis method was correlation analysis and hypothesis testing. The correlation matrix was derived during the analysis.

H1- There is a significant relationship between each green practice in freight transportation and differentiation.

H0- There is no significant relationship between each green practice in freight transportation and differentiation.

\section{Analysis:-}

This section is on the results obtained through the data analysis conducted using the SPSS software.

The sample of the current study consists with organizations which transport freight through land, sea and air. Out of seventy five questionnaires which were distributed, only sixty two organizations responded with a response rate of 82.6 percent.

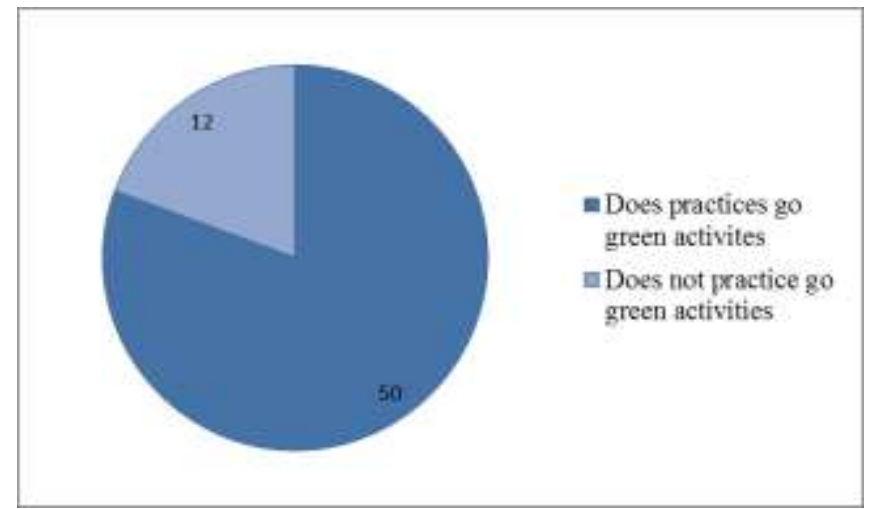

Figure 3:- Organizations which practice green practices

Out of sixty two organizations only fifty organizations fulfilled the defining criteria which was put forward by the current study. From the sixty two organizations fifty organizations (66.6 percent of total respondents) are practicing green freight activities whereas twelve organizations out of the respondents do not practice go green activities to transport freight as depicted in Figure 3.

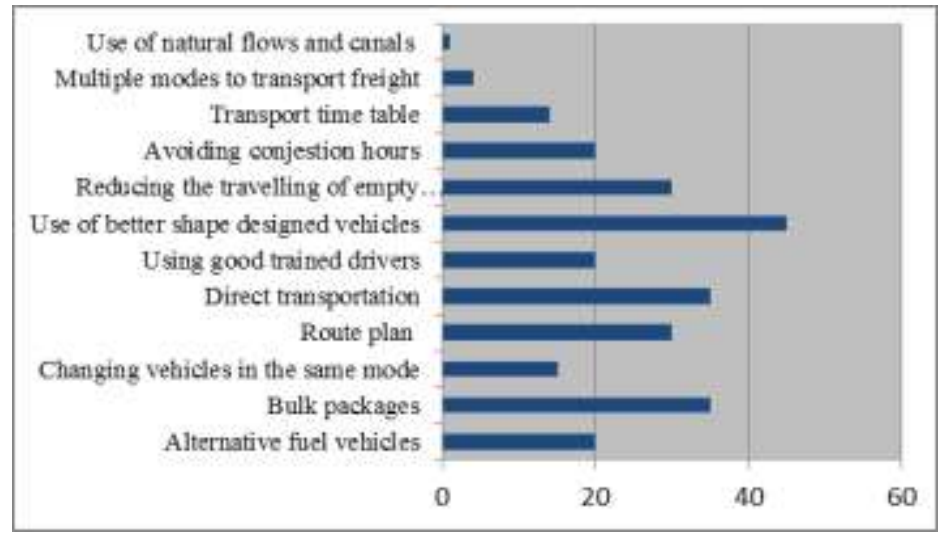

Figure 4:- Usage of different green freight practices by organizations

The Figure 4 shows how the selected twelve green practices are used in the transportation process of these organizations. It can be observed that the shape and size of the vehicle is the most popular concern of the transporters.

Table 1:- KMO and Bartleet's Test 


\begin{tabular}{|l|l|l|}
\hline \multicolumn{2}{|l|}{ Kaiser-Meyer-Olkin Measure of Sampling Adequacy } & .631 \\
\hline Bartlett's Test of Sphericity & Approx. Chi-Square & 502.521 \\
\hline & Df & 78 \\
\hline & Sig. & .000 \\
\hline
\end{tabular}

The sample adequacy can be considered as acceptable since it has a value of 0.631 in the KMO test as shown in the

Table 2:- Model summary

\begin{tabular}{|l|r|r|r|r|}
\hline Model & R & R Square & Adjusted R Square & \multicolumn{2}{|c|}{$\begin{array}{c}\text { Std. Error of the } \\
\text { Estimate }\end{array}$} \\
\hline 1 & $.845^{\text {a }}$ & .714 & .622 & .555 \\
\hline
\end{tabular}

As shown in the Table 2, the $\mathrm{R}$ squared value is $71.4 \%$ which depicts that $71.4 \%$ of the variance of the model is explained by the variables considered.

Table 3:- Cronbach alpha value

\begin{tabular}{|r|r|}
\hline Cronbach's Alpha & N of Items \\
\hline
\end{tabular}

The Cronbach's alpha indicates the internal consistency of the data set that is obtained and as depicted in Table 3 the value is 0.527 (more than 0.5 ) and this states that the reliability of the data is acceptable.

Table 4 depicts the correlation analysis results. A strong correlation between some of the independent variables and the dependent variable is visible through Table 4.

The correlation between the use of alternative vehicles and differentiation is 13 percent. Therefore it has a positive but very weak correlation. Also the relationship between these two variables is insignificant.

Transporting items in bulk packages has a 57.3 percent correlation with differentiation. Therefore it can be stated that there is a positive strong correlation between transporting in bulk packages and differentiation. Further there is a significant relationship between these two variables at 90 percent significance level.

The correlation between the change of vehicles within the same mode and differentiation is 18.2 percent. Therefore it is a positive but very weak correlation which exists between change of vehicles within the same mode and differentiation. Also the relationship between these two variables is insignificant. The correlation between the use of route planning and differentiation is 16 percent. Therefore it has a positive but very weak correlation. Also the relationship between these two variables is insignificant.

The practice of direct transportation to the sites has a correlation of 61.6 percent with differentiation. Hence it has a positive and very strong correlation. Additionally the relationship between these two variables is significant at 90 percent significance level.

The correlation between the use of trained drivers and differentiation is 46.9 percent which indicates a moderately strong correlation between the use of trained drivers and differentiation which is also a positive correlation. Additionally the relationship between these two variables is significant at 90 percent significant level. The correlation between use of vehicles with improved shapes and differentiation is 17.4 percent. Therefore it is a positive but very weak correlation which exists between use of vehicles with improved shapes and differentiation.

The correlation between the reduction of empty travelling of vehicles and differentiation is 46.3 percent which indicates a moderately strong correlation but it is a negative correlation that can be observed. Further the relationship between reduction of empty travelling of vehicles and differentiation is significant at 90 percent significance level. The correlation between the avoiding of travel during congested hours and differentiation is 31.5 percent which indicates a weak correlation between the practice of avoiding travel during congested hours and differentiation which is also a positive correlation. Additionally the relationship between these two variables is significant at 95 percent significant level. 
The use of a transport time tables has a 57.6 percent correlation with differentiation. Hence the use of a transport time tables has a strong and positive correlation with differentiation. Additionally the relationship between these two variables is significant at 90 percent significance level. Use of multiple modes for freight transportation has a correlation of 34.9 percent with differentiation. Therefore it is a weak but positive correlation. On the other hand the relationship between these two variables is significant at 95 percent significant level.

The correlation between the use of natural flows and canals and differentiation is 23.8 percent and it is a weak negative correlation.

Table 4 summaries and illustrates the correlation and the significance of the relationships among the independent variables and the dependent variable.

\section{Discussion:-}

This section discusses the findings of the analysis and interprets the results obtained in the previous section.

This study has analyzed the relationship between different green freight practices and differentiation of freight transport organizations. Through the results obtained in the analysis it can be stated that not all green freight strategies contribute towards differentiation. Certain practices have positive correlations with differentiation while some have negative correlations with differentiation. Use of alternative vehicles, transporting in bulk packages, change of vehicles within the same mode, use of direct transportation, use of route planning, using of trained drivers, use of vehicles with improved shapes, avoiding congestion hours, using a transport time table and using multiple modes to transport freight have positive correlations with differentiation. Transporting goods in bulk packages, direct transportation to the sites, use of trained drivers and using a transport time table have significantly strong positive correlations with differentiation (at the significance level of 90 percent). Therefore these practices will help organizations to differentiate themselves from other competitors in the freight transport field. Reduction of empty vehicle travelling has a significant negative relationship with differentiation. Therefore will not help the differentiation strategy of organizations although it is an environmentally friendly practice.

\section{Conclusion:-}

This section concludes the study while discussing the limitations of it and suggests areas for further research.

This research was conducted to identify the relationship between green freight transport practices and differentiation. The primary objective of this study was to analyse the relationship between green freight transportation practices and differentiation of an organization in order to gain competitive advantage. As the sample of the study initially, seventy five companies were selected in Colombo district. Only sixty two responses were acceptable and out of that only fifty met the criteria required by this study. The sample was selected based on the convenience sampling method as it was difficult to obtain data from certain organizations. This study focused on freight transport organizations where green freight activities already exist. Primary data was obtained through a questionnaire survey and interviews with the executives and the management staff of organizations. Twelve green freight transport practices were considered. The relevant hypothesis were developed. SPSS was used for data analysis. The correlation matrix was derived during the analysis. The $\mathrm{R}$ squared value was $71.4 \%$ which depicts that $71.4 \%$ of the variance of the model is explained by the variables considered. Further the findings state that there is a positive relationship between ten of the green practices out of the twelve practices considered by the study, with differentiation strategy. The ten practices are use of alternative vehicles, transporting in bulk packages, change of vehicles within the same mode, use of direct transportation, use of route planning, using of trained drivers, use of vehicles with improved shapes, avoiding congestion hours, using a transport time table and using multiple modes to transport freight have positive correlations with differentiation.

Transporting goods in bulk packages, direct transportation to the sites, use of trained drivers and using a transport time table have significantly strong positive correlations with differentiation (at the significance level of 90 percent). Therefore it can be recommended that the implementation of practices such as transporting in bulk packages, direct transportation, using of trained drivers and using a transport time table contributes to enhance the differentiation of freight transporters. Also avoiding travel at congested times and use of multiple modes for freight transportation 
have significant relationships with differentiation, but the positive correlation between these practices and differentiation is weak.

The limitations of this study were that it was restricted to the Colombo district and the size of organizations was not considered. As further research it can be suggested that the relationship between these practices and each main differentiation strategy be analyzed. Also the motivation and intention of organizations which have not yet adopted green freight practices to move towards the adoption of such practices can be studied upon.

Table 4:- Correlation Analysis

\begin{tabular}{|c|c|c|c|c|c|c|c|c|c|c|c|c|c|c|}
\hline & & $\begin{array}{l}\text { Altern } \\
\text { ative } \\
\text { fuel } \\
\text { vehicl } \\
\text { es }\end{array}$ & $\begin{array}{l}\text { Bulk } \\
\text { pack } \\
\text { ages }\end{array}$ & $\begin{array}{l}\text { Chan } \\
\text { ging } \\
\text { vehic } \\
\text { les in } \\
\text { the } \\
\text { same } \\
\text { mode }\end{array}$ & $\begin{array}{c}\text { Ro } \\
\text { ute } \\
\text { pla } \\
\mathrm{n}\end{array}$ & $\begin{array}{c}\text { Direct } \\
\text { transpo } \\
\text { rtation }\end{array}$ & $\begin{array}{c}\text { Usi } \\
\text { ng } \\
\text { goo } \\
\text { d } \\
\text { trai } \\
\text { ned } \\
\text { driv } \\
\text { ers }\end{array}$ & $\begin{array}{c}\text { Use } \\
\text { of } \\
\text { bette } \\
\mathrm{r} \\
\text { shap } \\
\mathrm{e} \\
\text { desi } \\
\text { gned } \\
\text { vehi } \\
\text { cles }\end{array}$ & $\begin{array}{c}\text { Redu } \\
\text { cing } \\
\text { the } \\
\text { trave } \\
\text { lling } \\
\text { of } \\
\text { empt } \\
y \\
\text { vehic } \\
\text { les }\end{array}$ & $\begin{array}{l}\text { Avoi } \\
\text { ding } \\
\text { conje } \\
\text { stion } \\
\text { hours }\end{array}$ & $\begin{array}{l}\text { Tran } \\
\text { sport } \\
\text { time } \\
\text { table }\end{array}$ & $\begin{array}{c}\text { Mult } \\
\text { iple } \\
\text { mod } \\
\text { es to } \\
\text { trans } \\
\text { port } \\
\text { freig } \\
\text { ht }\end{array}$ & $\begin{array}{c}\text { Use } \\
\text { of } \\
\text { natu } \\
\text { ral } \\
\text { flo } \\
\text { ws } \\
\text { and } \\
\text { can } \\
\text { als }\end{array}$ & $\begin{array}{l}\text { differe } \\
\text { ntiaton }\end{array}$ \\
\hline \multirow{5}{*}{$\begin{array}{l}\text { Alterna } \\
\text { tive } \\
\text { fuel } \\
\text { vehicle } \\
\text { s }\end{array}$} & $\begin{array}{l}\text { Pears } \\
\text { on } \\
\text { Correl } \\
\text { ation }\end{array}$ & 1 & -.175 & .162 & $\begin{array}{r}.13 \\
2\end{array}$ & -.086 & $\begin{array}{r}.03 \\
5\end{array}$ & .124 & .016 & -.003 & -.058 & $\begin{array}{r}- \\
.039\end{array}$ & .016 & .130 \\
\hline & $\begin{array}{l}\text { Sig. } \\
(2- \\
\text { tailed })\end{array}$ & & .225 & .260 & $\begin{array}{r}.36 \\
0\end{array}$ & .554 & $\begin{array}{r}.80 \\
8\end{array}$ & .390 & .915 & .986 & .688 & .786 & .910 & .369 \\
\hline & $\begin{array}{l}\text { Sum } \\
\text { of } \\
\text { Squar } \\
\text { es and } \\
\text { Cross- } \\
\text { produ } \\
\text { cts }\end{array}$ & $\begin{array}{r}12.32 \\
0\end{array}$ & $\begin{array}{r}- \\
2.08 \\
0\end{array}$ & 1.720 & $\begin{array}{r}2.2 \\
00\end{array}$ & -1.640 & $\begin{array}{r}.40 \\
0\end{array}$ & $\begin{array}{r}2.16 \\
0\end{array}$ & .160 & -.040 & $1.080^{-}$ & $\begin{array}{r}- \\
.680\end{array}$ & .200 & 2.880 \\
\hline & $\begin{array}{l}\text { Covar } \\
\text { iance }\end{array}$ & .251 & -.042 & .035 & $\begin{array}{r}.04 \\
5 \\
\end{array}$ & -.033 & $\begin{array}{r}.00 \\
8 \\
\end{array}$ & .044 & .003 & -.001 & -.022 & $\begin{array}{r}- \\
.014 \\
\end{array}$ & .004 & .059 \\
\hline & $\mathrm{N}$ & 50 & 50 & 50 & 50 & 50 & 50 & 50 & 50 & 50 & 50 & 50 & 50 & 50 \\
\hline \multirow[t]{5}{*}{$\begin{array}{l}\text { Bulk } \\
\text { packag } \\
\text { es }\end{array}$} & $\begin{array}{l}\text { Pears } \\
\text { on } \\
\text { Correl } \\
\text { ation }\end{array}$ & -.175 & 1 & -.066 & $\begin{array}{r}.07 \\
5\end{array}$ & $.387^{* * *}$ & $\begin{array}{r}.30 \\
9^{*}\end{array}$ & .176 & $.406^{-}$ & -.084 & $\begin{array}{r}.419^{*} \\
*\end{array}$ & $\begin{array}{r}.294 \\
*\end{array}$ & $\begin{array}{r}- \\
.323\end{array}$ & $.573^{* * *}$ \\
\hline & $\begin{array}{l}\text { Sig. } \\
(2- \\
\text { tailed) }\end{array}$ & .225 & & .647 & $\begin{array}{r}.60 \\
7\end{array}$ & .006 & $\begin{array}{r}.02 \\
9\end{array}$ & .222 & .003 & .562 & .002 & .038 & .022 & .000 \\
\hline & $\begin{array}{l}\text { Sum } \\
\text { of } \\
\text { Squar } \\
\text { es and } \\
\text { Cross- } \\
\text { produ } \\
\text { cts }\end{array}$ & -2.080 & $\begin{array}{r}11.5 \\
20\end{array}$ & -.680 & $\begin{array}{r}1.2 \\
00\end{array}$ & 7.160 & $\begin{array}{r}3.4 \\
00\end{array}$ & $\begin{array}{r}2.96 \\
0\end{array}$ & $\begin{array}{r}- \\
4.04 \\
0\end{array}$ & $1.240^{-}$ & 7.520 & $\begin{array}{r}4.92 \\
0\end{array}$ & $\begin{array}{r}- \\
3.80 \\
0\end{array}$ & 12.280 \\
\hline & $\begin{array}{l}\text { Covar } \\
\text { iance }\end{array}$ & -.042 & .235 & -.014 & $\begin{array}{r}.02 \\
4 \\
\end{array}$ & .146 & $\begin{array}{r}.06 \\
9 \\
\end{array}$ & .060 & -.082 & -.025 & .153 & .100 & $\begin{array}{r}- \\
.078 \\
\end{array}$ & .251 \\
\hline & $\mathrm{N}$ & 50 & 50 & 50 & 50 & 50 & 50 & 50 & 50 & 50 & 50 & 50 & 50 & 50 \\
\hline \multirow{2}{*}{$\begin{array}{l}\text { Changi } \\
\text { ng } \\
\text { vehicle } \\
\mathrm{s} \text { in the } \\
\text { same } \\
\text { mode }\end{array}$} & $\begin{array}{l}\text { Pears } \\
\text { on } \\
\text { Correl } \\
\text { ation } \\
\end{array}$ & .162 & -.066 & 1 & $\begin{array}{r}- \\
.12 \\
6\end{array}$ & .034 & $\begin{array}{r}.14 \\
3\end{array}$ & $\begin{array}{r}- \\
.176\end{array}$ & .154 & .241 & -.105 & $\begin{array}{r}- \\
.086\end{array}$ & .115 & .182 \\
\hline & $\begin{array}{l}\text { Sig. } \\
(2- \\
\text { tailed) } \\
\end{array}$ & .260 & .647 & & $\begin{array}{r}.38 \\
5\end{array}$ & .815 & $\begin{array}{r}.32 \\
2\end{array}$ & .221 & .286 & .092 & .468 & .553 & .428 & .205 \\
\hline
\end{tabular}




\begin{tabular}{|c|c|c|c|c|c|c|c|c|c|c|c|c|c|c|}
\hline & $\begin{array}{l}\text { Sum } \\
\text { of } \\
\text { Squar } \\
\text { es and } \\
\text { Cross- } \\
\text { produ } \\
\text { cts }\end{array}$ & 1.720 & -.680 & 9.120 & $\begin{array}{r}- \\
1.8 \\
00\end{array}$ & .560 & $\begin{array}{r}1.4 \\
00\end{array}$ & $\begin{array}{r}- \\
2.64 \\
0\end{array}$ & $\begin{array}{r}1.36 \\
0\end{array}$ & 3.160 & $1.680^{-}$ & $\begin{array}{r}- \\
1.28 \\
0\end{array}$ & $\begin{array}{r}1.20 \\
0\end{array}$ & 3.480 \\
\hline & $\begin{array}{l}\text { Covar } \\
\text { iance }\end{array}$ & .035 & -.014 & .186 & $\begin{array}{r}.03 \\
7 \\
\end{array}$ & .011 & $\begin{array}{r}.02 \\
9\end{array}$ & .054 & .028 & .064 & -.034 & .026 & .024 & .071 \\
\hline & $\mathrm{N}$ & 50 & 50 & 50 & 50 & 50 & 50 & 50 & 50 & 50 & 50 & 50 & 50 & 50 \\
\hline \multirow[t]{5}{*}{$\begin{array}{l}\text { Route } \\
\text { plan }\end{array}$} & $\begin{array}{l}\text { Pears } \\
\text { on } \\
\text { Correl } \\
\text { ation }\end{array}$ & .132 & .075 & -.126 & 1 & -.112 & $\begin{array}{r}- \\
.22 \\
8\end{array}$ & .132 & .007 & .029 & -.052 & .051 & .000 & .160 \\
\hline & $\begin{array}{l}\text { Sig. } \\
(2- \\
\text { tailed) }\end{array}$ & .360 & .607 & .385 & & .439 & $\begin{array}{r}.11 \\
2\end{array}$ & .361 & .960 & .841 & .721 & .723 & $\begin{array}{r}1.00 \\
0\end{array}$ & .267 \\
\hline & $\begin{array}{l}\text { Sum } \\
\text { of } \\
\text { Squar } \\
\text { es and } \\
\text { Cross- } \\
\text { produ } \\
\text { cts }\end{array}$ & 2.200 & $\begin{array}{r}1.20 \\
0\end{array}$ & $1.800^{-}$ & $\begin{array}{r}22 . \\
500\end{array}$ & -2.900 & $\begin{array}{r}- \\
3.5 \\
00\end{array}$ & $\begin{array}{r}3.10 \\
0\end{array}$ & .100 & .600 & $1.300^{-}$ & $\begin{array}{r}1.20 \\
0\end{array}$ & .000 & 4.800 \\
\hline & $\begin{array}{l}\text { Covar } \\
\text { iance }\end{array}$ & .045 & .024 & -.037 & $\begin{array}{r}.45 \\
9\end{array}$ & -.059 & $\begin{array}{r}- \\
.07 \\
1 \\
\end{array}$ & .063 & .002 & .012 & -.027 & .024 & .000 & .098 \\
\hline & $\mathrm{N}$ & 50 & 50 & 50 & 50 & 50 & 50 & 50 & 50 & 50 & 50 & 50 & 50 & 50 \\
\hline \multirow[t]{5}{*}{$\begin{array}{l}\text { Direct } \\
\text { transpo } \\
\text { rtation }\end{array}$} & $\begin{array}{l}\text { Pears } \\
\text { on } \\
\text { Correl } \\
\text { ation }\end{array}$ & -.086 & $.387_{*}^{*}$ & .034 & $\begin{array}{r}- \\
.11 \\
2\end{array}$ & 1 & $\begin{array}{l}.71 \\
8^{* * *}\end{array}$ & $\begin{array}{r}- \\
.252\end{array}$ & $.302^{*}$ & $.299^{*}$ & $.646^{*}$ & .162 & $\begin{array}{r}. \\
.074\end{array}$ & $.616^{* * *}$ \\
\hline & $\begin{array}{l}\text { Sig. } \\
(2- \\
\text { tailed) }\end{array}$ & .554 & .006 & .815 & $\begin{array}{r}.43 \\
9\end{array}$ & & $\begin{array}{r}.00 \\
0\end{array}$ & .077 & .033 & .035 & .000 & .261 & .609 & .000 \\
\hline & $\begin{array}{l}\text { Sum } \\
\text { of } \\
\text { Squar } \\
\text { es and } \\
\text { Cross- } \\
\text { produ } \\
\text { cts }\end{array}$ & -1.640 & $\begin{array}{r}7.16 \\
0\end{array}$ & .560 & $\begin{array}{r}- \\
2.9 \\
00\end{array}$ & 29.780 & $\begin{array}{r}12 . \\
700\end{array}$ & $\begin{array}{r}- \\
6.82 \\
0\end{array}$ & $\begin{array}{r}- \\
4.82 \\
0\end{array}$ & 7.080 & $\begin{array}{r}18.66 \\
0\end{array}$ & $\begin{array}{r}4.36 \\
0\end{array}$ & $\begin{array}{r}- \\
1.40 \\
0\end{array}$ & 21.240 \\
\hline & $\begin{array}{l}\text { Covar } \\
\text { iance }\end{array}$ & -.033 & .146 & .011 & $\begin{array}{r}- \\
.05 \\
9\end{array}$ & .608 & $\begin{array}{r}.25 \\
9\end{array}$ & $.139^{-}$ & -.098 & .144 & .381 & .089 & $\begin{array}{r}- \\
.029\end{array}$ & .433 \\
\hline & $\mathrm{N}$ & 50 & 50 & 50 & 50 & 50 & 50 & 50 & 50 & 50 & 50 & 50 & 50 & 50 \\
\hline \multirow[t]{3}{*}{$\begin{array}{l}\text { Using } \\
\text { good } \\
\text { trained } \\
\text { drivers }\end{array}$} & $\begin{array}{l}\text { Pears } \\
\text { on } \\
\text { Correl } \\
\text { ation } \\
\end{array}$ & .035 & $.309^{*}$ & .143 & $\begin{array}{r}- \\
.22 \\
8\end{array}$ & $.718^{* * *}$ & 1 & $\begin{array}{r}- \\
.268\end{array}$ & -.242 & .156 & $.577^{*}$ & .025 & $\begin{array}{r}- \\
.089\end{array}$ & $.469^{* * *}$ \\
\hline & $\begin{array}{l}\text { Sig. } \\
(2- \\
\text { tailed) }\end{array}$ & .808 & .029 & .322 & $\begin{array}{r}.11 \\
2\end{array}$ & .000 & & .060 & .090 & .279 & .000 & .863 & .538 & .001 \\
\hline & $\begin{array}{l}\text { Sum } \\
\text { of } \\
\text { Squar } \\
\text { es and } \\
\text { Cross- } \\
\text { produ } \\
\text { cts }\end{array}$ & .400 & $\begin{array}{r}3.40 \\
0\end{array}$ & 1.400 & $\begin{array}{r}- \\
3.5 \\
00\end{array}$ & 12.700 & $\begin{array}{r}10 . \\
500\end{array}$ & $\begin{array}{r}- \\
4.30 \\
0\end{array}$ & $\begin{array}{r}- \\
2.30 \\
0\end{array}$ & 2.200 & 9.900 & .400 & $\begin{array}{r}- \\
1.00 \\
0\end{array}$ & 9.600 \\
\hline
\end{tabular}




\begin{tabular}{|c|c|c|c|c|c|c|c|c|c|c|c|c|c|c|}
\hline & $\begin{array}{l}\text { Covar } \\
\text { iance }\end{array}$ & .008 & .069 & .029 & $\begin{array}{r}- \\
.07 \\
1\end{array}$ & .259 & $\begin{array}{r}.21 \\
4\end{array}$ & $\begin{array}{r}- \\
.088\end{array}$ & -.047 & .045 & .202 & .008 & $.020^{-}$ & .196 \\
\hline & $\mathrm{N}$ & 50 & 50 & 50 & 50 & 50 & 50 & 50 & 50 & 50 & 50 & 50 & 50 & 50 \\
\hline \multirow{5}{*}{$\begin{array}{l}\text { Use of } \\
\text { better } \\
\text { shape } \\
\text { designe } \\
\text { d } \\
\text { vehicle } \\
\text { s }\end{array}$} & $\begin{array}{l}\text { Pears } \\
\text { on } \\
\text { Correl } \\
\text { ation }\end{array}$ & .124 & .176 & -.176 & $\begin{array}{r}.13 \\
2\end{array}$ & -.252 & $\begin{array}{r}- \\
.26 \\
8\end{array}$ & 1 & $.718^{*}$ & -.163 & .246 & .825 & $\begin{array}{r}- \\
.722 \\
* *\end{array}$ & .174 \\
\hline & $\begin{array}{l}\text { Sig. } \\
(2- \\
\text { tailed })\end{array}$ & .390 & .222 & .221 & $\begin{array}{r}.36 \\
1\end{array}$ & .077 & $\begin{array}{r}.06 \\
0\end{array}$ & & .000 & .257 & .085 & .000 & .000 & .228 \\
\hline & $\begin{array}{l}\text { Sum } \\
\text { of } \\
\text { Squar } \\
\text { es and } \\
\text { Cross- } \\
\text { produ } \\
\text { cts }\end{array}$ & 2.160 & $\begin{array}{r}2.96 \\
0\end{array}$ & $2.640^{-}$ & $\begin{array}{r}3.1 \\
00\end{array}$ & -6.820 & $\begin{array}{r}- \\
4.3 \\
00\end{array}$ & $\begin{array}{r}24.5 \\
80\end{array}$ & $\begin{array}{r}- \\
10.4 \\
20\end{array}$ & $3.520^{-}$ & 6.460 & $\begin{array}{r}20.1 \\
60\end{array}$ & $\begin{array}{r}- \\
12.4 \\
00\end{array}$ & 5.440 \\
\hline & $\begin{array}{l}\text { Covar } \\
\text { iance }\end{array}$ & .044 & .060 & -.054 & $\begin{array}{r}.06 \\
3\end{array}$ & -.139 & $\begin{array}{r}- \\
.08 \\
8\end{array}$ & .502 & -.213 & -.072 & .132 & .411 & $\begin{array}{r}- \\
.253\end{array}$ & .111 \\
\hline & $\mathrm{N}$ & 50 & 50 & 50 & 50 & 50 & 50 & 50 & 50 & 50 & 50 & 50 & 50 & 50 \\
\hline \multirow{5}{*}{$\begin{array}{l}\text { Reduci } \\
\text { ng the } \\
\text { travelli } \\
\text { ng of } \\
\text { empty } \\
\text { vehicle } \\
\text { s }\end{array}$} & $\begin{array}{l}\text { Pears } \\
\text { on } \\
\text { Correl } \\
\text { ation } \\
\end{array}$ & .016 & $.406^{*}$ & .154 & $\begin{array}{r}.00 \\
7\end{array}$ & $-.302^{*}$ & $\begin{array}{r}- \\
.24 \\
2\end{array}$ & $.718^{-}$ & 1 & -.041 & $.809^{-}$ & $\begin{array}{r}- \\
.750 \\
* *\end{array}$ & .650 & $-.463^{* * *}$ \\
\hline & $\begin{array}{l}\text { Sig. } \\
(2- \\
\text { tailed }) \\
\end{array}$ & .915 & .003 & .286 & $\begin{array}{r}.96 \\
0\end{array}$ & .033 & $\begin{array}{r}.09 \\
0\end{array}$ & .000 & & .778 & .000 & .000 & .000 & .001 \\
\hline & $\begin{array}{l}\text { Sum } \\
\text { of } \\
\text { Squar } \\
\text { es and } \\
\text { Cross- } \\
\text { produ } \\
\text { cts }\end{array}$ & .160 & $\begin{array}{r}- \\
4.04 \\
0\end{array}$ & 1.360 & $\begin{array}{r}.10 \\
0\end{array}$ & -4.820 & $\begin{array}{r}- \\
2.3 \\
00\end{array}$ & $\begin{array}{r}- \\
10.4 \\
20\end{array}$ & $\begin{array}{r}8.58 \\
0\end{array}$ & -.520 & $\begin{array}{r}- \\
12.54 \\
0\end{array}$ & $\begin{array}{r}- \\
10.8 \\
40\end{array}$ & $\begin{array}{r}6.60 \\
0\end{array}$ & -8.560 \\
\hline & $\begin{array}{l}\text { Covar } \\
\text { iance }\end{array}$ & .003 & -.082 & .028 & $\begin{array}{r}.00 \\
2\end{array}$ & -.098 & $\begin{array}{r}- \\
.04 \\
7 \\
\end{array}$ & $.213^{-}$ & .175 & -.011 & -.256 & .221 & .135 & -.175 \\
\hline & $\mathrm{N}$ & 50 & 50 & 50 & 50 & 50 & 50 & 50 & 50 & 50 & 50 & 50 & 50 & 50 \\
\hline \multirow[t]{5}{*}{$\begin{array}{l}\text { Avoidi } \\
\text { ng } \\
\text { conjesti } \\
\text { on } \\
\text { hours }\end{array}$} & $\begin{array}{l}\text { Pears } \\
\text { on } \\
\text { Correl } \\
\text { ation }\end{array}$ & -.003 & -.084 & .241 & $\begin{array}{r}.02 \\
9\end{array}$ & $.299^{*}$ & $\begin{array}{r}.15 \\
6\end{array}$ & $\begin{array}{r}- \\
.163\end{array}$ & -.041 & 1 & $.337^{*}$ & $\begin{array}{r}- \\
.142\end{array}$ & .372 & $.315^{*}$ \\
\hline & $\begin{array}{l}\text { Sig. } \\
(2- \\
\text { tailed) }\end{array}$ & .986 & .562 & .092 & $\begin{array}{r}.84 \\
1\end{array}$ & .035 & $\begin{array}{r}.27 \\
9\end{array}$ & .257 & .778 & & .017 & .326 & .008 & .026 \\
\hline & $\begin{array}{l}\text { Sum } \\
\text { of } \\
\text { Squar } \\
\text { es and } \\
\text { Cross- } \\
\text { produ } \\
\text { cts }\end{array}$ & -.040 & $\begin{array}{r}- \\
1.24 \\
0\end{array}$ & 3.160 & $\begin{array}{r}.60 \\
0\end{array}$ & 7.080 & $\begin{array}{r}2.2 \\
00\end{array}$ & $\begin{array}{r}- \\
3.52 \\
0\end{array}$ & -.520 & $\begin{array}{r}18.88 \\
0\end{array}$ & 7.760 & $\begin{array}{r}- \\
3.04 \\
0\end{array}$ & $\begin{array}{r}5.60 \\
0\end{array}$ & 8.640 \\
\hline & $\begin{array}{l}\text { Covar } \\
\text { iance }\end{array}$ & -.001 & -.025 & .064 & $\begin{array}{r}.01 \\
2 \\
\end{array}$ & .144 & $\begin{array}{r}.04 \\
5 \\
\end{array}$ & $\begin{array}{r}- \\
.072 \\
\end{array}$ & -.011 & .385 & .158 & $\begin{array}{r}- \\
.062 \\
\end{array}$ & .114 & .176 \\
\hline & $\mathrm{N}$ & 50 & 50 & 50 & 50 & 50 & 50 & 50 & 50 & 50 & 50 & 50 & 50 & 50 \\
\hline $\begin{array}{l}\text { Transp } \\
\text { ort time } \\
\text { table }\end{array}$ & $\begin{array}{l}\text { Pears } \\
\text { on } \\
\text { Correl } \\
\text { ation } \\
\end{array}$ & -.058 & $\begin{array}{r}.419^{*} \\
*\end{array}$ & -.105 & $\begin{array}{r}- \\
.05 \\
2\end{array}$ & $.646^{* * *}$ & $\begin{array}{l}.57 \\
7^{* * *}\end{array}$ & .246 & $\begin{array}{r}- \\
{ }^{*}\end{array}$ & $.337^{*}$ & 1 & .380 & $\begin{array}{r}- \\
.262\end{array}$ & $.576^{* * *}$ \\
\hline
\end{tabular}




\begin{tabular}{|c|c|c|c|c|c|c|c|c|c|c|c|c|c|c|}
\hline & $\begin{array}{l}\text { Sig. } \\
(2- \\
\text { tailed) }\end{array}$ & .688 & .002 & .468 & $\begin{array}{r}.72 \\
1\end{array}$ & .000 & $\begin{array}{r}.00 \\
0\end{array}$ & .085 & .000 & .017 & & .006 & .066 & .000 \\
\hline & $\begin{array}{l}\text { Sum } \\
\text { of } \\
\text { Squar } \\
\text { es and } \\
\text { Cross- } \\
\text { produ } \\
\text { cts }\end{array}$ & -1.080 & $\begin{array}{r}7.52 \\
0\end{array}$ & $1.680^{-}$ & $\begin{array}{r}- \\
1.3 \\
00\end{array}$ & 18.660 & $\begin{array}{r}9.9 \\
00\end{array}$ & $\begin{array}{r}6.46 \\
0\end{array}$ & $\begin{array}{r}- \\
12.5 \\
40\end{array}$ & 7.760 & $\begin{array}{r}28.02 \\
0\end{array}$ & $\begin{array}{r}9.92 \\
0\end{array}$ & $\begin{array}{r}- \\
4.80 \\
0\end{array}$ & 19.280 \\
\hline & $\begin{array}{l}\text { Covar } \\
\text { iance }\end{array}$ & -.022 & .153 & -.034 & $\begin{array}{r}.02 \\
7 \\
\end{array}$ & .381 & $\begin{array}{r}.20 \\
2\end{array}$ & .132 & -.256 & .158 & .572 & .202 & $\begin{array}{r}- \\
.098\end{array}$ & .393 \\
\hline & $\mathrm{N}$ & 50 & 50 & 50 & 50 & 50 & 50 & 50 & 50 & 50 & 50 & 50 & 50 & 50 \\
\hline \multirow{5}{*}{$\begin{array}{l}\text { Multipl } \\
\text { e } \\
\text { modes } \\
\text { to } \\
\text { transpo } \\
\text { rt } \\
\text { freight }\end{array}$} & $\begin{array}{l}\text { Pears } \\
\text { on } \\
\text { Correl } \\
\text { ation }\end{array}$ & -.039 & $.294^{*}$ & -.086 & $\begin{array}{r}.05 \\
1\end{array}$ & .162 & $\begin{array}{r}.02 \\
5\end{array}$ & .825 & $.750^{*}$ & -.142 & $.380_{*}^{*}$ & 1 & $\begin{array}{r}- \\
.866 \\
* *\end{array}$ & $.349^{*}$ \\
\hline & $\begin{array}{l}\text { Sig. } \\
(2- \\
\text { tailed) }\end{array}$ & .786 & .038 & .553 & $\begin{array}{r}.72 \\
3\end{array}$ & .261 & $\begin{array}{r}.86 \\
3\end{array}$ & .000 & .000 & .326 & .006 & & .000 & .013 \\
\hline & $\begin{array}{l}\text { Sum } \\
\text { of } \\
\text { Squar } \\
\text { es and } \\
\text { Cross- } \\
\text { produ } \\
\text { cts }\end{array}$ & -.680 & $\begin{array}{r}4.92 \\
0\end{array}$ & $1.280^{-}$ & $\begin{array}{r}1.2 \\
00\end{array}$ & 4.360 & $\begin{array}{r}.40 \\
0\end{array}$ & $\begin{array}{r}20.1 \\
60\end{array}$ & $\begin{array}{r}- \\
10.8 \\
40\end{array}$ & $3.040^{-}$ & 9.920 & $\begin{array}{r}24.3 \\
20\end{array}$ & $\begin{array}{r}- \\
14.8 \\
00\end{array}$ & 10.880 \\
\hline & $\begin{array}{l}\text { Covar } \\
\text { iance }\end{array}$ & -.014 & .100 & -.026 & $\begin{array}{r}.02 \\
4 \\
\end{array}$ & .089 & $\begin{array}{r}.00 \\
8 \\
\end{array}$ & .411 & -.221 & -.062 & .202 & .496 & $.302^{-}$ & .222 \\
\hline & $\mathrm{N}$ & 50 & 50 & 50 & 50 & 50 & 50 & 50 & 50 & 50 & 50 & 50 & 50 & 50 \\
\hline \multirow[t]{5}{*}{$\begin{array}{l}\text { Use of } \\
\text { natural } \\
\text { flows } \\
\text { and } \\
\text { canals }\end{array}$} & $\begin{array}{l}\text { Pears } \\
\text { on } \\
\text { Correl } \\
\text { ation } \\
\end{array}$ & .016 & $.323^{*}$ & .115 & $\begin{array}{r}.00 \\
0\end{array}$ & -.074 & $\begin{array}{r}- \\
.08 \\
9\end{array}$ & $\begin{array}{r}- \\
.722 \\
* * *\end{array}$ & $\begin{array}{r}.650^{*} \\
*\end{array}$ & $.372^{*}$ & -.262 & $\begin{array}{r}- \\
.866 \\
* * *\end{array}$ & 1 & -.238 \\
\hline & $\begin{array}{l}\text { Sig. } \\
(2- \\
\text { tailed) }\end{array}$ & .910 & .022 & .428 & $\begin{array}{r}1.0 \\
00\end{array}$ & 609 & $\begin{array}{r}.53 \\
8\end{array}$ & .000 & .000 & .008 & .066 & .000 & & .097 \\
\hline & $\begin{array}{l}\text { Sum } \\
\text { of } \\
\text { Squar } \\
\text { es and } \\
\text { Cross- } \\
\text { produ } \\
\text { cts }\end{array}$ & .200 & $\begin{array}{r}- \\
3.80 \\
0\end{array}$ & 1.200 & $\begin{array}{r}.00 \\
0\end{array}$ & -1.400 & $\begin{array}{r}- \\
1.0 \\
00\end{array}$ & $\begin{array}{r}- \\
12.4 \\
00\end{array}$ & $\begin{array}{r}6.60 \\
0\end{array}$ & 5.600 & $4.800^{-}$ & $\begin{array}{r}- \\
14.8 \\
00\end{array}$ & $\begin{array}{r}12.0 \\
00\end{array}$ & -5.200 \\
\hline & $\begin{array}{l}\text { Covar } \\
\text { iance }\end{array}$ & .004 & -.078 & .024 & $\begin{array}{r}.00 \\
0\end{array}$ & -.029 & $\begin{array}{r}- \\
.02 \\
0\end{array}$ & .253 & .135 & .114 & -.098 &. & .245 & -.106 \\
\hline & $\mathrm{N}$ & 50 & 50 & 50 & 50 & 50 & 50 & 50 & 50 & 50 & 50 & 50 & 50 & 50 \\
\hline \multirow[t]{3}{*}{$\begin{array}{l}\text { differen } \\
\text { tiaton }\end{array}$} & $\begin{array}{l}\text { Pears } \\
\text { on } \\
\text { Correl } \\
\text { ation }\end{array}$ & .130 & $.573^{*}$ & .182 & $\begin{array}{r}.16 \\
0\end{array}$ & $.616^{* * *}$ & $\begin{array}{l}.46 \\
9^{* * *}\end{array}$ & .174 & $.463^{*}$ & $.315^{*}$ & $.576_{*}^{*}$ & .349 & $\begin{array}{r}- \\
.238\end{array}$ & 1 \\
\hline & $\begin{array}{l}\text { Sig. } \\
(2- \\
\text { tailed) }\end{array}$ & .369 & .000 & .205 & $\begin{array}{r}.26 \\
7\end{array}$ & .000 & $\begin{array}{r}.00 \\
1\end{array}$ & .228 & .001 & .026 & .000 & .013 & .097 & \\
\hline & $\begin{array}{l}\text { Sum } \\
\text { of } \\
\text { Squar } \\
\text { es and } \\
\text { Cross- }\end{array}$ & 2.880 & $\begin{array}{r}12.2 \\
80\end{array}$ & 3.480 & $\begin{array}{r}4.8 \\
00\end{array}$ & 21.240 & $\begin{array}{r}9.6 \\
00\end{array}$ & $\begin{array}{r}5.44 \\
0\end{array}$ & $\begin{array}{r}- \\
8.56 \\
0\end{array}$ & 8.640 & $\begin{array}{r}19.28 \\
0\end{array}$ & $\begin{array}{r}10.8 \\
80\end{array}$ & $\begin{array}{r}- \\
5.20 \\
0\end{array}$ & 39.920 \\
\hline
\end{tabular}




\begin{tabular}{|c|c|c|c|c|c|c|c|c|c|c|c|c|c|c|}
\hline & $\begin{array}{l}\text { produ } \\
\text { cts }\end{array}$ & & & & & & & & & & & & & \\
\hline & $\begin{array}{l}\text { Covar } \\
\text { iance }\end{array}$ & .059 & .251 & .071 & $\begin{array}{r}.09 \\
8\end{array}$ & .433 & $\begin{array}{r}.19 \\
6\end{array}$ & .111 & -.175 & .176 & .393 & .222 & $\begin{array}{r}- \\
.106\end{array}$ & .815 \\
\hline & $\mathrm{N}$ & 50 & 50 & 50 & 50 & 50 & 50 & 50 & 50 & 50 & 50 & 50 & 50 & 50 \\
\hline
\end{tabular}

\section{References:-}

1. Buhler, $\mathrm{G}$ and Jochem, $\mathrm{P}$ (n.d.): $\mathrm{CO} 2$ Emission Reduction in Freight Transports: How to Stimulate Environmental Friendly Behaviour? SSRN Electronic Journal. Available from: doi:10.2139/ssrn.1266095. [Accessed: $9^{\text {th }}$ February 2017]

2. Lo, S (2013): Effects of supply chain position on the motivation and practices of firms going green. International Journal of Operations \& Productions Management. 34 (1). pp 93-114. Available from: doi:10.1108/ijopm-04-2012-0133. [Accessed: 20 ${ }^{\text {th }}$ March 2017]

3. Marchet, G; Melacini, M and Perotti, S (2014): Environmental sustainability in logistics and freight transportation, Journal of Manufacturing Technology Management. 25 (6). pp.775-811. Available from: doi:10.1108/jmtm-06-2012-0065. [Accessed: $9^{\text {th }}$ March 2017]

4. Pålsson, H and Kovács, G (2014): Reducing transportation emissions, International Journal of Physical Distribution \& Logistics Management. 44 (4). pp. 283-304. Available from: doi:10.1108/ijpdlm-09-2012-0293. [Accessed: 14 $4^{\text {th }}$ August 2017]

5. Staš, D; Lenort, R; Wicher, P and Holman, D (2015): Green Transport Balanced Scorecard Model with Analytic Network Process Support, Sustainability. 7 (11). pp.15243-15261. Available from: doi:10.3390/su71115243. [Accessed: $7^{\text {th }}$ July 2017]. 